\title{
SOSIAL DETERMINAN DAN PERILAKU MEROKOK DI INDONESIA (ANALISA DATA RISKESDAS TAHUN 2013)
}

\author{
Determinants Social Behavior and Smoking in Indonesia (Analysis of data Riskesdas in 2013)
}

\author{
1*Nurhalina \\ ${ }^{1}$ Program Study Analyst Health, Universitas Muhammadiyah Palangkaraya, Jl. RTA. Milono Km. 1,5, Palangka Raya, Indonesia \\ *nurhalina@umpalangkaraya.ac.id
}

\begin{abstract}
ABSTRAK
Rokok merupakan masalah kesehatan masyarakat karena dapat memicu berbagai macam penyakit bagi perokok dan masyarakat di sekitarnya. Rokok membunuh lebih dari setengah pengunanya, hampir 6 juta orang pertahun yang terdiri dari perokok dan mantan perokok serta 600 ribu orang bukan perokok yang terpapar asap rokok. Bila tidak dilakukan pengendalian, kematian akibat rokok akan meningkat cepat menjadi 8 juta pada Tahun 2030. Prevalensi merokok di Indonesia mencapai 36.3 $\%$ pada Tahun 2013 dan mengenai semua lapisan masyarakat. Kecenderungan merokok terus meningkat dari tahun ke tahun baik pada laki-laki maupun perempuan Tulisan ini menggambarkan perilaku merokok dengan tujuan untuk mendeskripsikan perilaku merokok berdasarkan umur, jenis kelamin, tempat tinggal, pendidikan, pekerjaan, kuantil indeks kepemilikan dan jumlah rokok yang diisap perhari. Sumber data adalah data sekunder Riskesdas 2013 yang dianalisis secara komprehensif melalui telaah pustaka dan teori. Hasil menunjukan bahwa umur 34-54 tahun, jenis kelamin laki-laki, tempat tinggal di pedesaan, pendidikan rendah dan mempunyai pekerjaan dengan kuantil indeks kepemilikan kebawah sampai menengah ke bawah merupakan faktor determinan yang cukup bermakna terhadap perilaku merokok di indonesia.
\end{abstract}

Kata kunci : Perilaku, Merokok, Riskesdas 2013

\section{ABSTRACT}

Smoking is a public health problem because it can lead to various diseases for smokers and the people around him. Cigarettes kill more than half pengunanya, nearly 6 million people a year are made up of smokers and former smokers and 600 thousand non-smokers exposed to secondhand smoke. When you do not control, tobacco-related deaths will rise rapidly to 8 million in the year 2030. The prevalence of smoking in Indonesia reached 36.3\% in the year 2013, and on all levels of society. Smoking trends continue to increase from year to year both in men and women alike This paper describes the smoking behavior with the aim to describe the behavior of smoking by age, gender, place of residence, education, employment, the index quintile ownership and number of cigarettes smoked per day. The source of data is secondary data Riskesdas 2013 that comprehensively analyzed through literature review and theory. The results showed that the age of 34-54 years, male gender, residence in rural, low education and have jobs with proprietary index quintile down to lower middle is a fairly significant determinant factor on smoking behavior in Indonesia.

Keyword: Behavior, Smoking, Riskesdas 2013

\section{PENDAHULUAN}

WHO menyebutkan bahwa jumlah perokok terus mengalami peningkatan selama dua dekade terakhir dan menjadi ancaman kesehatan masyarakat. Tembakau membunuh lebih setengah penggunanya, hampir 6 juta orang pertahun diantaranya 5 juta orang perokok dan mantan perokok, serta 600 ribu orang bukan perokok yang terpapar asap rokok. Bila tidak dilakukan tindakan pengendalian, kematian akan meningkat cepat menjadi 8 juta orang pada Tahun 2030 (WHO, 2012).

Indonesia merupakan negara ke tiga dengan jumlah perokok tertinggi di dunia setelah cina dan india. Berdasarkan Riset Kesehatan Dasar (Riskesdas) Tahun 2013, jumlah rata-rata batang rokok yang dihisap perhari adalah 12.3 batang (setara satu bungkus). Proporsi terbanyak perokok 
aktif setiap hari adalah kelompok umur produktif (25-64 tahun) dengan rentang 30.7 \%-32.2\% dan terjadi peningkatan proporsi perokok yang berusia $\geq 10$ tahun (36.3\%) jika dibandingkan dengan hasil Riskesdas Tahun 2010 (34.7 \%) (Kemenkes, 2013).

Prevalensi merokok di indonesia sangat tinggi di berbagai lapisan masyarakat terutama pada lakilaki, mulai dari anak, dewasa bahkan Balita. Pada Tahun 2013 diperkirakan 384.058 orang di Indonesia menderita penyakit yang berhubungan dengan perilaku merokok dan menyebabkan kematian 190.260 jiwa atau $12.7 \%$ dari total penyebab kematian utama di Indonesia. Ironinya kebijakan pengendalian tembakau di Indonesia masih menimbulkan perdebatan yang panjang, mulai dari hak asasi seorang perokok (Pusdatin kemenkes), fatwa haram merokok di tempat umum, hingga dampak rokok bagi perekonomian nasional. Fakta membuktikan bahwa bahaya merokok terhadap kesehatan sangat besar, jauh lebih dari yang disadari oleh sebagian besar masyarakat.

Berbagai avidence based menyatakan bahwa mengkonsumsi tembakau dapat menyebabkan Penyakit Kanker (Mulut, Pharinx, Larinx, Oesophagus, Paru, Pankreas dan Kandung Kemih), Penyakit Sistem Pembuluh Darah (Penyakit Jantung Koroner, Aneunisme Aorta, Pembuluh Darah Perifer, Arteriosklerosis, gamngguan pembuluh darah otak ), Sistem Pernapasan (Bronchitis, Chronis, Emfiisema, Pau, Obstruktif. Kronik, TB Paru, Asma dan penyakit saluran napas lainnya) (WHO, 2004). Kecenderungan merokok di Indonesia akan terus meningkat dari tahun ke tahun baik pada laki-laki maupun perempuan. Kendati demikian perilaku merokok dapat dikendalikan dengan mengenali determinan sosial yang menyertai perokok baik individu perokok maupun lingkungan sekitar. Informasi tersebut dapat dijadikan rujukan untuk pengendalian tembakau di Indonesia.

Tulisan ini akan menggambarkan perilaku merokok di indonesia berdasarkan determinan sosial dengan menggunakan data sekunder hasil Riskesdas Tahun 2013 dengan tujuan mendeskripsikan perilaku merokok di Indonesia berdasarkan umur, jenis kelamin, tempat tinggal, pendidikan, pekerjaan dan kuantil indeks kepemilikan.

Tulisan ini diharapkan dapat bermanfaat baik secara teoritis maupun secara praktis dalam rangka pengembangan ilmu pengetahuan dalam bidang kesehatan masyarakat dan dapat memberikan informasi kepada instansi terkait guna pengendalian tembakau di Indonesia.

\section{METODE PENELITIAN}

Riskesdas (Riset Kesehatan Dasar) 2013 adalah survei kesehatan nasional pada tingkat rumah tangga, representative terhadap tingkat kabupaten/ kota. Riskesdas ini dilaksanakan di 33 provinsi di indonesia dengan beberapa kabupaten terpilih dari setiap provinsi. Populasi yang dianalisa untuk studi ini adalah populasi yang berusia $\geq 10$ tahun. Determinan sosial (variabel independen) dalam studi ini adalah umur, jenis kelamin, tempat tinggal, pendidikan, pekerjaan, indeks kuantil kepemilikan (tingkat pengeluaran perkapita). Analisa terhadap data dilakukan dengan telaah pustaka dan teori serta mengevaluasi rata-rata $( \pm \mathrm{SD})$ usia perokok dengan determinan sosial lainya. Sedangkan untuk jumlah batang rokok yang dihisap perhari akan dilihat berdasarkan masing-masing determinan sosial dengan menggunakan prevalens. Analisas dilakukan dengan menggunakan SPPS versi 16.0.

\section{HASIL DAN PEMBAHASAN}

Studi ini menganalisis penduduk yang berumur 10 tahun ke atas sebanyak 177.926 responden yang terdiri dari laki-laki sebanyak 86.493 responden $(46.6 \%)$ dan perempuan sebanyak 91.433 (51.4 \%). Di perkotaan sebanyak 91.057 responden $(51.2 \%)$ dan pedesaan 86.869 responden (48.8 \%). Hasil Riskesdas menunjukan bahwa proporsi perokok di indonesia mengalami peningkatan, dimana hasil Riskesdas Tahun 2007 (32.4\%), Tahun 2010 (34.7\%) dan pada Tahun 2013 menjadi $36.3 \%$.

Tabel 1 menunjukan bahwa proporsi perokok aktif di indonesia (setiap hari) lebih besar (36.3\%) jika dibandingkan dengan perokok "kadang-kadang", $(5.0 \%)$. Sedangkan mantan perokok mencapai $4.0 \%$. Tabel 1 menunjukan bahwa proporsi perokok aktif paling tinggi di Provinsi Kepulauan Riau (27.2\%), Bengkulu (27.1\%), Jawa Barat (27.1\%), Bangka Belitung (26.7 \%) dan Lampung (26.5\%) dan paling sedikit di Provinsi Papua (16.3\%) dan Bali (18.0 $\%)$.Sedangkan proporsi penduduk yang mempunyai kebiasaan merokok "kadang-kadang" paling banyak 
di Provinsi Maluku (6.5\%), Nusa Tenggara Timur (6.2\%) dan paling sedikit di Provinsi Kalimantan Barat dan Bangka Belitung, masing-masing 3.1\%. Proporsi mantan perokok paling banyak di Provinsi D.I.Yogyakarta $(9.1 \%)$ dan DKI Jakarta $(6.0 \%)$. sedangkan proporsi bukan perokok paling banyak di Provinsi Papua $(75.4 \%)$ dan paling sedikit di Provinsi Jawa Barat $(62.8 \%)$.

Tabel 1. Perilaku Merokok Berdasarkan Provinsi di Indonesia Tahun 2013 (Data sekunder, Riskesdas 2013)

\begin{tabular}{|c|c|c|c|c|}
\hline \multirow[b]{2}{*}{ Rovinsi } & \multicolumn{2}{|c|}{ Perokok Saat ini } & \multicolumn{2}{|c|}{ Tidak merokok } \\
\hline & $\begin{array}{l}\text { setiap Hari } \\
(\%)\end{array}$ & $\begin{array}{l}\text { Perokok Kadang- } \\
\text { kadang } \\
(\%)\end{array}$ & $\begin{array}{c}\text { Mantan perokok } \\
(\%)\end{array}$ & $\begin{array}{c}\text { Bukan perokok } \\
(\%)\end{array}$ \\
\hline Aceh & 25.0 & 4.3 & 2.5 & 68.2 \\
\hline Sumatera Utara & 24.2 & 4.2 & 3.3 & 68.2 \\
\hline Sumatera Barat & 26.4 & 3.9 & 3.1 & 66.0 \\
\hline Riau & 24.2 & 4.1 & 3.2 & 68.5 \\
\hline Jambi & 22.9 & 4.7 & 2.9 & 69.5 \\
\hline Sumatera Selatan & 24.7 & 5.4 & 3.4 & 66.6 \\
\hline Bengkulu & 27.1 & 3.3 & 2.4 & 67.2 \\
\hline Lampung & 26.5 & 4.8 & 2.6 & 66.0 \\
\hline Bangka Belitung & 26.7 & 3.1 & 3.6 & 66.6 \\
\hline Kepulauan Riau & 27.2 & 3.5 & 4.8 & 64.4 \\
\hline DKI Jakarta & 23.2 & 6.0 & 6.0 & 64.8 \\
\hline Jawa Barat & 27.1 & 5.6 & 4.5 & 62.8 \\
\hline Jawa Tengah & 22.9 & 5.3 & 4.3 & 67.6 \\
\hline DI Yogyakarta & 21.2 & 5.7 & 9.1 & 64.1 \\
\hline Jawa Timur & 23.9 & 5.0 & 4.1 & 67.0 \\
\hline Banten & 26.0 & 5.3 & 3.3 & 65.3 \\
\hline Bali & 18.0 & 4.4 & 4.6 & 73.0 \\
\hline Nusa Tenggara Barat & 26.8 & 3.5 & 2.2 & 67.5 \\
\hline Nusa Tenggara Timur & 19.7 & 6.2 & 2.4 & 71.6 \\
\hline Kalimantan Barat & 23.6 & 3.1 & 2.7 & 70.0 \\
\hline Kalimantan Tengah & 22.5 & 4.0 & 3.1 & 69.8 \\
\hline Kalimantan Selatan & 22.1 & 3.6 & 4.6 & 69.8 \\
\hline Kalimantan Timur & 23.3 & 4.4 & 4.2 & 68.1 \\
\hline Sulawesi Utara & 24.6 & 5.9 & 6.2 & 63.3 \\
\hline Sulawesi Tengah & 26.2 & 4.5 & 4.4 & 64.9 \\
\hline Sulawesi Selatan & 22.8 & 4.2 & 4.6 & 68.5 \\
\hline Sulawesi Tenggara & 21.8 & 4.2 & 2.8 & 71.1 \\
\hline Gorontalo & 26.8 & 5.5 & 3.4 & 64.3 \\
\hline Sulawesi Barat & 22.0 & 4.2 & 3.6 & 70.2 \\
\hline Maluku & 22.1 & 6.5 & 2.0 & 69.4 \\
\hline Maluku Utara & 25.8 & 6.1 & 4.1 & 64.0 \\
\hline Papua Barat & 22.1 & 6.0 & 2.6 & 69.3 \\
\hline Papua & 16.3 & 5.6 & 2.8 & 75.4 \\
\hline Indonesia & 31.3 & 5.0 & 4.0 & 66.6 \\
\hline
\end{tabular}




\begin{tabular}{|c|c|c|}
\hline \multirow{2}{*}{ Karakteristik } & \multicolumn{2}{|c|}{ Perokok Saat Ini } \\
\hline & $\begin{array}{c}\text { Perokok } \\
\text { Setiap Hari } \\
(\%)\end{array}$ & $\begin{array}{c}\text { Perokok } \\
\text { Kadang-Kadang } \\
(\%)\end{array}$ \\
\hline \multicolumn{3}{|l|}{ Kelompok Umur (tahun) } \\
\hline $10-14$ & 0.5 & 0.9 \\
\hline $15-19$ & 11.2 & 7.1 \\
\hline $20-24$ & 27.2 & 6.9 \\
\hline $25-29$ & 29.8 & 5.0 \\
\hline $30-34$ & 33.4 & 5.1 \\
\hline $35-39$ & 32.2 & 5.2 \\
\hline $40-44$ & 31.0 & 5.4 \\
\hline $45-49$ & 31.4 & 5.5 \\
\hline $50-54$ & 31.4 & 5.3 \\
\hline $55-59$ & 30.3 & 5.0 \\
\hline $60-64$ & 27.6 & 4.8 \\
\hline $65+$ & 21.7 & 5.1 \\
\hline \multicolumn{3}{|l|}{ Jenis kelamin } \\
\hline Laki-laki & 47.5 & 9.2 \\
\hline Perempuan & 1.1 & 0.8 \\
\hline \multicolumn{3}{|l|}{ Pendidikan } \\
\hline Tidak sekolah & 19.7 & 3.1 \\
\hline Tidak tamat SD & 18.3 & 3.2 \\
\hline Tamat SD & 25.2 & 4.5 \\
\hline Tamat SMP & 25.7 & 5.7 \\
\hline Tamat SMA & 28.7 & 6.6 \\
\hline Tamat D1-D3/PT & 18.9 & 5.6 \\
\hline \multicolumn{3}{|l|}{ Pekerjaan } \\
\hline Tidak bekerja & 6.9 & 3.0 \\
\hline Pegawai & 33.6 & 7.4 \\
\hline Wiraswasta & 39.8 & 6.5 \\
\hline Petani/nelayan/buruh & 44.5 & 6.9 \\
\hline Lain-lain & 32.4 & 5.8 \\
\hline \multicolumn{3}{|l|}{ Tempat Tinggal } \\
\hline Perkotaan & 23.2 & 5.1 \\
\hline Perdesaan & 25.5 & 4.9 \\
\hline \multicolumn{3}{|l|}{ Kuantil Indeks Kepemilikan } \\
\hline Terbawah & 27.3 & 5.0 \\
\hline Menengah Bawah & 26.9 & 5.1 \\
\hline Menengah & 25.5 & 5.1 \\
\hline Menengah Atas & 23.5 & 5.0 \\
\hline Teratas & 19.5 & 4.7 \\
\hline
\end{tabular}

Tabel 2 menunjukan bahwa mereka yang merokok setiap hari paling banyak adalah mereka yang berumur 30-34 tahun (33.4\%) dan 35-39 tahun ( $32.2 \%)$. Berdasarkan jenis kelamin, paling banyak adalah laki-laki (47.5 $\%)$ dan perempuan hanya berkisar $1.1 \%$. Sedangkan berdasarkan aspek pendidikan, paling banyak adalah mereka yang tamat SMA (28.7\%) dan paling sedikit adalah mereka yang tamat D1-D3/PT (18.9\%).
Pada aspek pekerjaan yang paling banyak adalah kelompok petani/ nelayan/ buruh (44\%) dan paling sedikit adalah mereka yang tidak bekerja $(6.9 \%)$. Berdasarkan tempat tinggal, paling banyak berasal dari pedesaan $(2.5 \%)$ sedangkan yang berasal dari perkotaan sekitar $23.2 \%$. Sedangkan berdasarkan kuantil indeks kepemilikan yang paling banyak adalah kuantil indeks terbawah $(23.7 \%)$ dan paling sedikit adalah mereka yang berada pada kuantil indeks kepemilikan teratas $(19.5 \%)$. 
Gambar 1 menunjukan bahwa rata-rata perokok di Indonesia mengisap 12.3 batang/ hari. Dimana jumlah tertinggi di Provinsi Bangka Belitung (18.3 batang/ hari), Kalimantan Selatan (16.6 batang/ hari) dan Riau (16.5 batang/ hari). Sedangkan jumlah yang paling rendah di Provinsi D.I.Yogyakarta (9.9 batang/ hari) dan Jawa Tengah (10.1 batang/ hari).

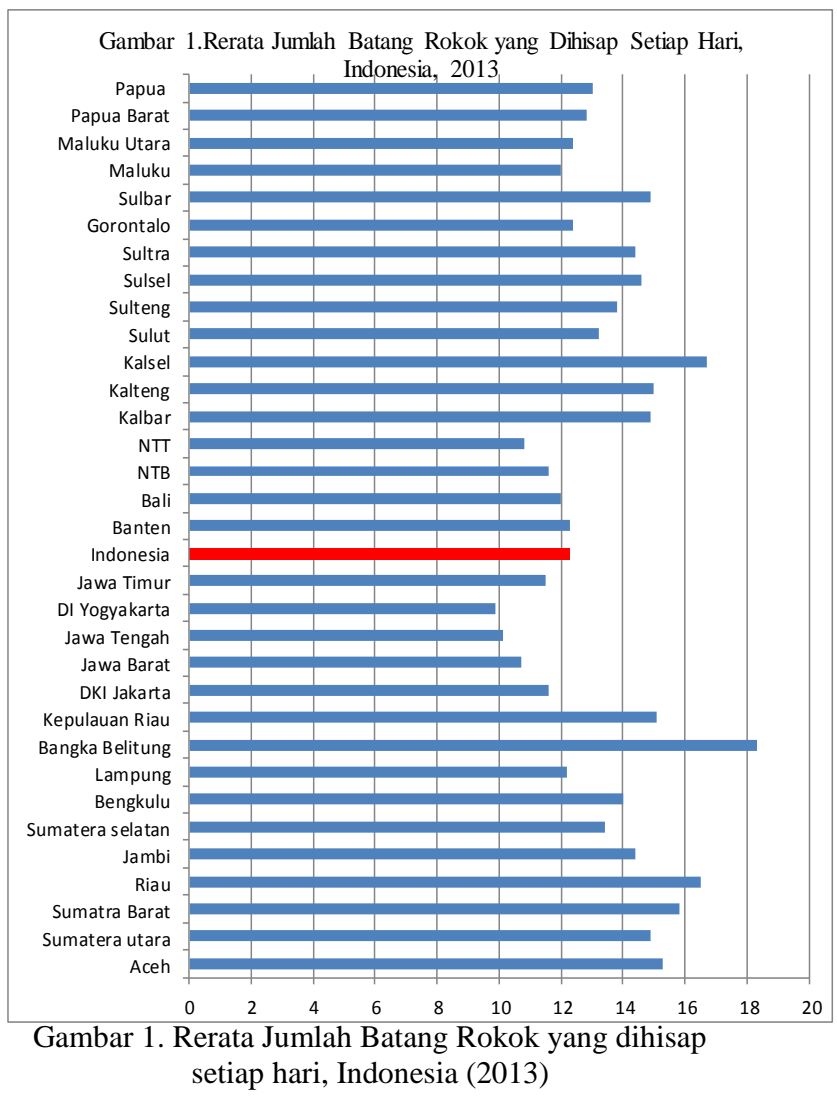

Hasil Riskesdas Tahun 2013 menunjukan bahwa jumlah perokok di Indonesia semakin meningkat pada semua kelompok umur, jika dibandingkan data Riskesdas Tahun 2007 dan 2010. Padahal pemeritah telah berupaya untuk menekan jumlah perokok dengan memberlakukan berbagai kebijakan, misalnya menaikan cukai dan pajak rokok serta memberlakukan kebijakan Kawasan Tanpa Rokok (KTR) namun usaha-usaha tersebut belum maksimal. Proporsi perokok aktif (merokok setiap hari) di indonesia lebih besar jumlahnya (36.3\%) jika dibandingkan dengan perokok "kadang-kadang"' (5.0\%). Sedangkan mantan perokok pada Tahun 2013 hanya berkisar $4.0 \%$. Menurut Han dan Payne
(2003), peningkatan jumlah perokok karena individu lebih mudah ketergantungan nikotin dibandingkan alkohol, cafein dan heroin. Pada saat merokok nikotin masuk ke paru-paru lalu menuju ke peredaran darah dan otak serta memberikan reaksi yang cepat dengan sel-sel otak dalam waktu 5-10 menit. Menurut Floyd, Mimms dan Yelding (2003), nikotin adalah kandungan tembakau yang berfungsi sebagai stimulant yang menyebabkan peningkatan detak jantung dan tekanan darah sehingga perokok lebih bersemangat lebih mampu berkosentrasi dan memiliki respon yang cepat. Selain itu nikotin pada rokok dapat menimbulkan ketagihan sehingga perokok cenderung sulit untuk berhenti merokok bahkan perokok "kadang-kadang" dapat berubah menjadi perokok aktif.

Rendahnya proporsi penduduk yang mantan perokok menunjukan bahwa mengurangi rokok atau berhenti mengkonsumsi rokok bukan hal yang mudah karena terbentuknya perilaku merokok dipengaruhi oleh beberapa faktor. Penelitian Lailatul et al (2015) menyatakan bahwa sebagian besar perokok pernah mencoba berhenti merokok namun mengalami kegagalan, antara lain karena tidak tahu caranya, merasa sulit berkosentrasi jika tidak merokok dan sebagian kecil karena keterikatan dengan sponsor rokok. Sementara itu ada yang berhasil berhenti merokok karena beberapa alasan, antara lain adanya kesadaran sendiri $(76 \%)$, telah mengalami penyakit (16 $\%)$ dan tuntutan profesi $(8 \%)$.

Menurut Barber (2001), penghentian atau pengurangan merokok berdampak terhadap fisiologis dan psikologis. Efek fisiologis antara lain sakit kepala, nyeri otot, keram, mual dan gangguan penglihatan yang biasanya berlangsung selama seminggu setelah penghentian rokok. Sedangkan dampak psikologis yang muncul antara lain adalah cemas, mudah tersinggung, kurang bersemangat dan mengantuk. Penelitian Kumboyono (2011), gejala psikologis adalah hal yang paling sulit diatasi bahkan menjadi faktor penghambat motivasi perokok untuk berhenti merokok. Proses penghentian merokok 
nikotin mengakibatkan munculnya simptom withdrawal setelah beberapa jam sejak pengurangan konsumsi rokok dan intensitasnya meningkat pada hari pertama hingga hari ke-4 (empat). Simptom kembali muncul pada minggu ke-3 (tiga) hingga ke-4 (empat) disertai rasa lapar dan terjadi peningkatan berat badan mulai bulan ke-6 (enam) dan seterusnya. Namun ketidaknyamanan tersebut akan berakhir dalam beberapa hari minggu atau beberapa bulan sehingga tubuh kembali berfungsi efektif (Hahn \& Payne,2003).

$$
\text { Dalam penelitiannya Kumboyono }
$$

(2011) juga menemukan informasi bahwa keengganan seseorang berhenti merokok karena perokok cenderung memiliki persepsi bahwa penyakit akibat yang ditimbulkan rokok tidak berbahaya jika dibandingkan dengan penyakit lainnya dan dampak yang dirasakan individu berbeda-beda tergantung determinan masingmasing. Dalam hal ini prilaku akan selalu dihubungkan dengan determinan sosial serta konsekuensi perubahan-perubahan yang terjadi seperti umur, jenis kelamin, tempat tinggal, pendidikan, pekerjaan dan status sosial ekonomi.

\section{Umur}

Data Riskesdas ini menunjukan bahwa mereka yang perokok setiap hari paling banyak berumur 30-34 tahun (33.4\%) dan angka ini stabil hingga berumur 59 tahun lalu menurun pada kelompok umur $>59$ tahun. Penelitian Fawzani dan Tritarnawati (2005), seorang yang telah lanjut usia cenderung tidak merokok karena kondisi fisik yang tidak sehat sehingga membutuhkan perawatan atau pengobatan tertentu. Feist dan Branon (2007) mengatakan bahwa pola merokok yang konsisten mulai terbentuk pada usia dewasa awal sehingga lebih mudah membentuk keyakinan terhadap kesehatannya. Dari data ini juga diperoleh informasi bahwa angka perokok pada remaja terus mengalami peningkatan yang signifikan, sebesar $0.5 \%$ perokok aktif pada kelompok umur 10-14 tahun dan $7.1 \%$ pada kelompok umur 15-19 tahun. Munculnya fenomena perokok di kalangan remaja menjadi perhatian tersendiri di dunia kesehatan karena remaja adalah pemegang estafet kepemimpinan bangsa. Kebiasaan merokok pada masa remaja dapat memberikan dampak negatif yang sangat berbahaya jika dibandingkan dengan perokok secara umum karena rokok dapat menjadi jembatan yang membawa individu kepada bahaya yang lebih besar seperti bahaya narkoba, seks bebas dan kriminalitas.

Penelitian Molina (2017), menunjukan bahwa sikap permisif orang tua terhadap perilaku merokok remaja dan lingkungan sebaya merupakan prediktor yang cukup baik terhadap perilaku berisiko remaja. Sejalan dengan penelitian Theodorus (1994) bahwa keluarga perokok sangat berperan terhadap perilaku merokok anak-anaknya dibandingkan keluarga non perokok. Kecenderungan peningkatan usia mulai merokok terutama pada usia dini mengalami peningkatan yang tinggi bahkan sudah dimulai pada usia Balita. Hal ini menunjukan lemahnya kontrol sosial masyarakat sekitar yang mengizinkan anak usia Balita merokok. Tentunya juga karena faktor lingkungan eksternal dimana keterpaparan informasi seperti iklan rokok melalui TV maupun papan iklan mempengaruhi mereka untuk meniru dan mencoba merokok dan akhirnya menjadi kebiasaan sehari-hari.

Penelitian Dian Komalasari dan Evin Fadila Helmi (2014), menunjukan bahwa kepuasan psikologis memberikan sumbangan yang sangat tinggi terhadap perilaku merokok pada remaja. Hasil ini semakin memperkuat pandangan bahwa merokok tidak berkaitan dengan rasional yaitu aspek negatif dari rokok baik dari sisi ekonomis, maupun kesehatan tetapi lebih berkaitan dengan kepuasan emosional. Penelitian Molina (2017), merokok dapat menjadi sebuah cara bagi remaja agar mereka tampak bebas dan dewasa saat mereka menyesuaikan diri dengan teman-teman sebayanya yang merokok, tekanan-tekanan teman sebaya, penampilan diri, rasa ingin tahu, stress, kebosanan, ingin kelihatan gagah, dan sikap suka menentang. Sedangkan faktor lainnya adalah rasa rendah diri, hubungan antar perorangan yang jelek, kurang mampu 
mengatasi stress, putus sekolah dan kondisi sosial ekonomi.

\section{Jenis Kelamin}

Laki-laki merupakan kelompok dominan sebagai perokok aktif di mana-mana. Hasil Riskesdas Tahun 2013, menunjukan bahwa perokok aktif (setiap hari) pada mereka yang berjenis kelamin laki-laki adalah $47.5 \%$ dan perempuan hanya $1.1 \%$. Hal tersebut relevan dengan Global Adult Tabaco Survey, dimana prevalensi perokok pada pria sebesar $67.0 \%$ dan wanita $2.7 \%$ dari 59.9 juta orang dewasa saat ini (GATS, 2015). Begitupula dengan data yang dirilis oleh The Tabaco Atlas (2015) dimana $66 \%$ laki-laki di indonesia adalah perokok. Penelitian Martini (2014), tingginya perokok pada pria karena adanya anggapan bahwa rokok identik dengan kejantanan seseorang, sehingga apabila seorang pria tidak merokok maka akan mendapat streotip dari lingkungan sekitar. Selain itu makna merokok bagi remaja putri, merokok adalah simbol sikap keren, simbol pemberontakan dan sebagai cara untuk mendapat kenikmatan. Merokok juga adalah teman setia dan teman untuk berbagi. Menurut Fawzani dan Tritarnawati (2005), tingginya jumlah perokok pada pria karena memiliki kesulitan yang lebih kompleks untuk berhenti merokok dibanding wanita karena salah satu alasan wanita untuk merokok adalah menjaga keseimbangan berat badan dan mengendalikan tingkat stress.

\section{Tempat Tinggal}

Data Riskesdas Tahun 2013 menunjukan bahwa wilayah pedesaan (rural) memiliki proporsi yang lebih tinggi (25.5\%) jika dibandingkan dengan wilayah urban (kota) yakni $23.2 \%$. Menurut swastika (2014), rendahnya proporsi perokok di perkotaan dipengaruhi oleh kesibukan penduduk untuk mencari nafkah sehingga tidak memiliki cukup waktu untuk bersantai yang memungkinkan mereka merokok. Selain itu tingkat pengetahuan masyarakat kota tentang bahaya rokok cukup memadai karena akses informasi publik yang relative lebih mudah diperoleh. Di sisi lain maraknya kebijakan KTR di kota-kota besar membatasi perilaku masyarakat untuk merokok di tempat-tempat umum sehingga kemungkinan mempengaruhi jumlah perokok di perkotaan. Menurut Volzke (2006), perilaku merokok penduduk perkotaan banyak dipengaruhi oleh gaya hidup yang cenderung lebih konsumtif jika dibandingkan dengan masyarakat di pedesaan. Selain itu tingkat stress akibat kebutuhan hidup yang tinggi menjadi pemicu utama perilaku merokok di perkotaan.

\section{Pendidikan}

Berdasarkan aspek pendidikan, hasil Riskesdas Tahun 2013 menunjukan bahwa proporsi perokok aktif (sehari-hari) paling banyak adalah mereka yang Tamat SMA (28.7 \%), Tamat SMP $(25.7 \%)$ dan Tamat SD (25.2 $\%)$. Sedangkan perokok "kadang-kadang" paling banyak adalah mereka yang Tamat SMA (66 \%), Tamat DI-D3/PT (5.6 \%) dan Tamat SMP (5.7 \%). Penelitian Silowati et al (2013), menunjukan bahwa tingkat pengetahuan dan pendidikan mempunyai hubungan yang signifikan bermakna terhadap perilaku merokok. Menurut Nursalam (2003), makin tinggi pendidikan seseorang semakin mudah pula mereka menerima informasi dan akhirnya makin banyak pula pengetahuan yang dimilikinya. Sebaliknya jika seseorang tingkat pendidikannya rendah akan menghambat perkembangan sikap seseorang terhadap penerimaan informasi dan nilai-nilai yang baru diperkenalkan. Berbeda dengan penelitian Komalasari dan Hemi (2014), kepuasan psikologis memberikan sumbangan yang sangat tinggi terhadap perilaku merokok. Artinya merokok tidak berkaitan dengan rasional yaitu aspek negatif dari rokok baik dari sisi ekonomis, maupun kesehatan tetapi lebih berkaitan dengan kepuasan emosional, kenikmatan dan kesenangan.

\section{Pekerjaan dan Kuantil Indeks Kepemilikan (Status Sosial Ekonomi)}

Hasil Riskesdas Tahun 2013 menunjukan bahwa proporsi perokok aktif (sehari-hari) maupun perokok 'kadang-kadang' paling sedikit adalah mereka yang tidak bekerja, masing-masing $6.9 \%$ dan $3.0 \%$. Sedangkan mereka yang bekerja baik sebagai pegawai, 
wiraswasta, petani/ buruh dan lain-lain menunjukan presentase yang cukup tinggi. Hal tersebut dimungkinkan karena para pekerja memiliki modal yang cukup untuk membeli rokok setiap hari dibandingkan dengan seseorang yang tidak bekerja. Demikian pula jika dilihat berdasarkan kuantil indeks kepemilikan bahwa semakin tinggi tingkat ekonomi seseorang maka perilaku merokok akan semakin menurun. Sejalan dengan penelitian Abdilah Hasan (2017), bahwa tingkat pendapatan/ ekonomi keluarga (kecuali kuantil 5) mempunyai hubungan yang signifikan dengan perilaku merokok seseorang. Menurut Cavallar dalam Paavolla, et al (2004), pada banyak negara berkembang prevalensi perilaku merokok menjadi lebih besar pada kelompok sosial ekonomi rendah. Dalam sebuah penelitian yang melibatkan para pelajar dari enam sekolah di Finlandia Timur ditemukan bahwa anak-anak dari para pekerja kerah biru (buruh) lebih banyak yang merokok dibandingkan anak-anak dari para pekerja kerah putih (pegawai kantor) atau petani.

\section{Jumlah Batang Rokok yang Dihisap Perhari}

Data ini menyebutkan bahwa rata-rata jumlah batang yang dihisap perhari orang indonesia adalah 12.3 batang/ hari. Dalam Riskedas Tahun 2013, proporsi jumlah rokok yang dihisap perhari juga dikelompokkan berdasarkan provinsi. Dimana jumlah tertinggi di Provinsi Bangka Belitung (18.3 batang/ hari), Kalimantan Selatan (16.6 batang/ hari) dan Riau (16.5 batang/ hari). Sedangkan jumlah yang paling rendah di Provinsi D.I.Yogyakarta (9.9 batang/ hari) dan Jawa Tengah (10.1 batang/ hari). Menurut Sitepoe (2000) perokok dapat dikategorikan berdasarkan jumlah konsumsi rokok harian yaitu : (1) perokok ringam (1-10 batang/ hari); (2) Perokok sedang (11-20 batang/ perhari) dan perokok berat (> 20 batang perhari). Perokok yang mengkonsumsi rokok lebih kecil memiliki kecenderungan lebih besar untuk berhenti merokok di kemudian hari. Berdasarkan data di atas maka rata-rata masyarakat indonesia tergolong perokok sedang. Menurut Scragg et al (2002) bahwa lingkungan kerja, lingkungan sosial, lingkungan sekolah, teman sepermainan dan kepatuhan terhadap kebijakan memiliki hubungan yang signifikan terhadap jumlah batang rokok yang dihisap perhari.

\section{KESIMPULAN DAN SARAN}

Perilaku merokok terjadi pada semua lapisan umur $>10$ tahun yang berjenis laki-laki maupun perempuan. Mereka yang berumur 1059 tahun, tinggal di daerah pedesaan dan juga tinggal di Pulau Sumatera dan Kalimantan dengan kuantil indeks kepemilikan menengah dan menegah ke bawah, memiliki pekerjaan serta memiliki pendidikan rendah merupakan faktor determinan yang cukup bermakna terhadap peningkatan jumlah perokok di indonesia. Kondisi faktor lingkungan sosial seperti tempat tinggal, pekerjaan, pendidikan dan kuantil indeks kepemilikan merupakan determinan variabel yang dapat dimodifikasi untuk mengurangi jumlah rokok yang dihisap perhari sehingga perokok dapat berupaya untuk berhenti merokok.

Berdasarkan kesimpulan di atas penulis menyarankan perlunya edukasi secara terus menerus dan terencana kepada semua lapisan masyarakat tentang dampak yang ditimbulkan akibat rokok. Selain itu diperlukan kebijakan yang memuat sanksi terhadap pelanggaran KTR.

\section{DAFTAR PUSTAKA}

Barber Joseph. (2001). Freedom from smoking:integrating hypnotic methods and rapid smoking to facilitate smoking cessation. The international journal of clinical and experimental hypnosis. 49(3)

Brannon, L., Feist, J., 2007. Health Psychology. 6 th. Ed. Belmon, CA: $97-130$

Bandura, Albert. 1997.Self Efficancy : The Exercise of Control. Freeman And Company : New York

Fawsani, N,.Tritarnawati.2013. Terapi Berhenti Merokok (Studi Kasus 3 Perokok Berat).Yogyakarta : Makara,Kesehatan.

Fawsani, N., Tritarnawati. 2013. Terapi Berhenti Merokok (Studi Kasus 3 
BJMLT

Perokok Berat). Yogyakarta :

Makara,Kesehatan.

Floyd,Mimms,.Yelding.2003.Personal Health: perspective and lifestyles.Wad USA

GATS.2015. Global Adults Tabacco Survey Indonesia Report. New Delhi : Regional

Hann,.Payne.2003.Focus On Health; Sixth Edition. Mc.Graw Hill : New York

Hasan, Abdillah. 2004. Pengaruh Faktor Sosial Ekonomi Terhadap Perilaku Individu; Analisis Data Susenan Tahun 2004. Universitas Indonesia

Jeanne, M, Wresniwiro. 1996. Masalah Narkotika dan Zat Aditif Lainnya. Serta Penanggulangannya. Jakarta: Pramuka Saka Bhayangkara.

Kementrian Kesehatan RI. 2014. Riset Kesehatan Dasar Tahun 2013. Jakarta

Komalasari, Dian, Hemi Avin Fadilla. 2014. Faktor-faktor Penyebab Perilaku merokok pada Remaja. Fakultas Kesehatan Masyarakat. Universitas Muhammadiyah Semarang

Kumboyono. 2011. Faktor Penghambat

Motivasi berhenti Merokok. Jurnal Keperawatan Soedirman. 6(1)

Larson,David,E.2003. Mayo Clinic Family Health Book : The Ultimate Home Medical Reference. $3^{\text {rd }}$ ed USA : Mayo Clinic

Martini, Sri. 2014. Makna Merokok Bagi Remaja Putri Perokok. Jurnal Psikologi Pendidikan dan Perkembangan. 3(2): 119-127

Molina. 2017. Hubungan Antara Konfirmitas Terhadap Perilaku Merokok pada Siswa SMP Negeri 1 Loa Janan. eJournal Psikologi. 5 (1) : 96-106

Natoadmodjo.2007. Ilmu Kesehatan Masyarakat. Jakarta : PT Rineka Cipta

Nursalam.2003. Konsep dan Penerapan Metodologi Penelitian Ilmu

Keperawatan. Jakarta: Salemba Medika

Paavola, Meri; Vartiainen, Erkki and Haukkala, Ari. 2004. Smoking From Adolescence to Adulthood, the Effects of Parental and Own Socioeconomic Status. European Journal of Public Health. 14(4): 417-420.
Rahma, Lailatul,. Sabrian,F. Karim D. 2015. Faktor pendukung dan penghambat Remaja Berhenti Merokok. JOM. 2(2)

Rachiotis, George; Muula, Adamson S; Rudatsikira, Emmanuel; Siziya, Seter; Kyrlesi, Athina; Gourgouliani, Konstantinos and Hadjichristodoulou, Christos. 2008. Factors Associated With Adolescent Cigarette Smoking in Greece: Results From A Cross Sectional Study (GYTS Study). BMC Public Health, 8: 313.

Scragg, Robert; Laugesen, Murray and Robinson, Elizabeth. 2002. Cigarette Smoking, Pocket Money and Socioeconomic Status: Results From A National Survey of $4^{\text {th }}$ Form Students in 2000. The New Zealand Medical Journal. 115

Silowati Nur, Lilis. 2012. Hubungan Tingkat Pengetahuan Tentang Merokok dengan Frekuensi Merokok pada Remaja Awal di Desa Gayam Kecamatan Sukoharjo. Fakultas Kesehatan Masyarakat. Universitas Muhammadiyah Semarang.

Sri Martini.2014. Makna Merokok Bagi Remaja Putri Perokok. Jurnal Psikologi Pendidikan dan Perkembangan. 3(2): 119-127.

Sitepoe, M. 2000. Kekhususan Rokok Indonesia. Jakarta : PT Grasindo.

Swastika, Dewa Ketut Sadra. 2014. Reformasi Paradigma Urbanisasi: Strategi Percepatan Pengentasan Kemiskinan di Pedesaan.. Jakarta: BadanPenelitian dan Pengembangan Pertanian

Theodorus. 1994.Ciri Perokok di Kalangan Mahasiswa/i Universitas Sriwijaya. Jurnal JEN . (3): 19-24.

Volzke, Henry. Et all. 2006. Urban-rural Disparities in Smoking Behaviour in Germany. BioMed 2006. 6:146

World Health Oorganization. 2012. WHO Global Report; Mortality Attribute in Tabacco.WHO Press : Jenewa

World Health Oorganization International Agency for Research On Cancer, 2004. IARCH Monograph on The Evaluation 


\section{BJMLT}

of carcinogenic Risks To Humans; In IARCH working Group (ed)). Tabacco Smoke and Involintary Smoking. IARC

Press : France 